\title{
Foramen magnum papilloma case report and review of the literature
}

\author{
Veranis Sotiris ${ }^{\mathrm{a},}$,, Karydakis Ploutarchos ${ }^{\mathrm{a}}$, Tsantopoulos Margaritis ${ }^{\mathrm{b}}$, Spanou Kallirroi ${ }^{\mathrm{b}}$, \\ Koutsoumpelis George ${ }^{\mathrm{a}}$
}

${ }^{a}$ Neurosurgical Department, 251 General Air Force and Reserve Hospital, Athens, Greece.

${ }^{b}$ Neuropathology Department, 251 General Air Force and Reserve Hospital, Athens, Greece.

\begin{abstract}
Atypical choroid plexus papillomas are rare in adults, especially in an extraventricular location.We present a case of a 42-year-old male patient suffering from a foramen magnum choroid plexus papilloma, which resembled meningioma in an initial evaluation, who developed dizziness, hearing loss, and gait disturbance. The patient was treated with suboccipital craniotomy and the tumor was partially removal. We describe the technique and postoperative complications. We also review other published cases of atypical choroid plexus papillomas of the posterior fossa in adults.
\end{abstract}

Keywords: Papilloma; foramen magnum; suboccipital craniotomy; posterior fossa

\section{INTRODUCTION}

Choroid plexus papilloma (CPP) is a rare tumor of neuroectodermal origin. It is more common in pediatric populations than adults and presents as a supratentorial mass in the former and a subtentorial mass in the latter. The 2016 World Health Organization classification classifies choroid plexus tumors as papillomas (grade I), atypical tumors (grade II) or carcinomas (grade III). Choroid plexus papillomas have less than two mitotic figures per 10 high power fields, while atypical tumors have two to five mitotic figures per 10 high power fields, and carcinomas have more than five mitotic figures per 10 high power fields. In general, the tumors are soft, globular, friable pink masses with irregular projections and high vascularity ${ }^{[1,2]}$.

The symptoms of choroid plexus papillomas of the posterior fossa include cranial nerves palsies (such as deafness or tinnitus), cerebellar dysfunction, and

\footnotetext{
* Corresponding author: Veranis Sotiris

Mailing address: 251 General Air Force and Reserve Hospital, 3-5 Kanellopoulou Street po box 11525, Athens, Greece.

E-mail: veranissotiris@gmail.com

Received: 13 May 2020 / Accepted: 28 August 2020
}

raised intracranial pressure, which can cause papilledema or blindness ${ }^{[1,2]}$.

In adults, a CPP is usually located inside the fourth ventricle. While extraventricular locations are rare, some CPPs arise in the foramen of Luschka and extend to the extraventricular area ${ }^{[3,4,5,6,7]}$. A rare case of multiple spinal drop metastases from CPP of the posterior fossa has also been published ${ }^{[8]}$.

Computed tomography (CT), magnetic resonance (MR), and rarely angiography are the initial diagnostic workup modalities. In adults, CPPs are weak enhancing tumors. Entrapped cysts containing CSF or peritumoral flow voids are occasionally seen, along with calcification in some cases.

In T2 imaging, tumors are iso- or hyperintense compared to cerebellar gray matter. In head CT scans, the tumor mass is usually isodense in precontrast images and hyperdense in postconstrast images compared to white matter ${ }^{[5,6]}$.

Angiographic images show that anterior or posterior inferior cerebellar arteries are largely responsible for the blood supply of CPP tumors ${ }^{[3]}$.

Surgery with complete resection can be curative in papillomas, with 5-year survival rates close to $100 \%$ and occasional recurrences. Radical surgery in carcinomas is difficult and usually requires adjuvant therapy. 
Table 1. Case reports publication with relevant pathology and surgical results.

\begin{tabular}{|c|c|c|c|c|c|c|}
\hline Article & $\begin{array}{l}\text { Patient } \\
\text { age/sex }\end{array}$ & Tumor Location & Pathology & Approach & Resection & Complication \\
\hline $\begin{array}{l}\text { Ignacio Jusué- } \\
\text { Torres et al }^{[1]}\end{array}$ & 38 male & $4^{\text {th }}$ ventricle & $\begin{array}{l}\text { Atypical choroid } \\
\text { papilloma }\end{array}$ & Telovellar & Total & None \\
\hline $\begin{array}{l}\text { Lechanoine } \mathrm{F} \\
\text { et } \mathrm{al}^{[4]}\end{array}$ & 47 male & $\begin{array}{l}\text { Cerebellomedullary } \\
\text { cistern }\end{array}$ & Benign CPP & $\begin{array}{l}\text { Midline suboccipital and } \\
\text { c1 partial laminectomy }\end{array}$ & Total & $\begin{array}{l}\text { None, preoperative hydro- } \\
\text { cephalus and Rinorrhea }\end{array}$ \\
\hline $\begin{array}{l}\text { van Swieten } \\
\text { JC et al }{ }^{[6]}\end{array}$ & 28 female & $4^{\text {th }}$ ventricle - CPA & Benign CPP & $\begin{array}{l}\text { Midline suboccipital } \\
\text { sitting position }\end{array}$ & Subtotal & None \\
\hline $\begin{array}{l}\text { van Swieten } \\
\text { JC et al }{ }^{[6]}\end{array}$ & 30 male & $\begin{array}{l}\text { Cerebellomedullary } \\
\text { cistern }\end{array}$ & Benign CPP & $\begin{array}{l}\text { Midline suboccipital } \\
\text { sitting position }\end{array}$ & Total & None \\
\hline $\begin{array}{l}\text { van Swieten } \\
\text { JC et al }{ }^{[6]}\end{array}$ & 64 female & CPA angle & Benign CPP & $\begin{array}{l}\text { Left suboccipital } \\
\text { sitting position }\end{array}$ & Total & Meningitis \\
\hline $\begin{array}{l}\text { Matsushita S } \\
\text { et al }{ }^{[7]}\end{array}$ & 42 female & $\begin{array}{l}\text { Left foramen of } \\
\text { Luschka }\end{array}$ & $\begin{array}{l}\text { Benign CPP with } \\
\text { focal ependymal } \\
\text { differentiation }\end{array}$ & $\begin{array}{l}\text { Preoperative emobilization } \\
\text { Suboccipital approach park } \\
\text { bench position }\end{array}$ & Total & Brain stem infraction \\
\hline $\begin{array}{l}\text { Symms NP } \\
\text { et al }{ }^{[9]}\end{array}$ & 61 male & $\begin{array}{l}4^{\text {th }} \text { ventricle and } \\
\text { foramen magnum }\end{array}$ & Benign CPP & $\begin{array}{l}\text { Midline suboccipital and c1 } \\
\text { partial laminectomy }\end{array}$ & Total & None \\
\hline Yu H et al ${ }^{[8]}$ & 49 male & $\begin{array}{l}\text { Conus medullaris, } \\
\text { C3-4, T7 }\end{array}$ & Atypical CPP & Staged excision & Partial & None \\
\hline
\end{tabular}

\section{Method}

We present the case of a 42-year-old man who reported to our clinic with symptoms of progressive headache, left-side deafness, diplopia, and episodes of sudden loss of consciousness. A clinical examination revealed unsteady gait, left-side nystagmus, and leftside deafness. After MRI and examination, a large mass at the left anterior foramen magnum was diagnosed (Figure 1). Calcification was observed on the upper part of the tumor, which was seated in the cerebellomedullary cistern. The tumor showed mild enhancement after contrast administration. The differential diagnosis was between meningioma of the foramen magnum and choroid plexus papilloma.

The patient was operated on under general anesthesia and in the prone position. A midline left suboccipital craniotomy and a left C1 laminectomy were performed. A microsurgical technique was used for tumor removal and detachment from critical structures, such as the

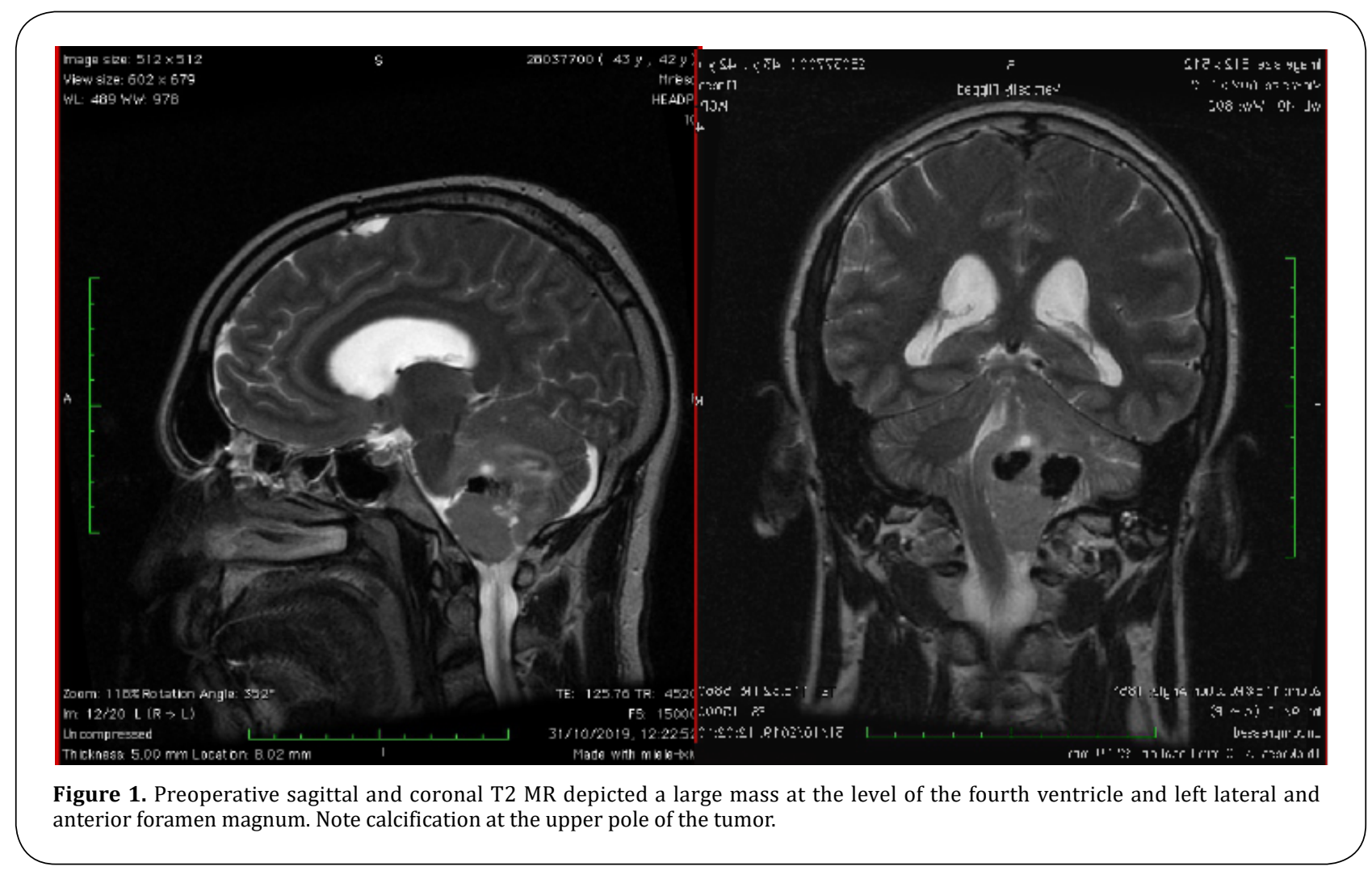




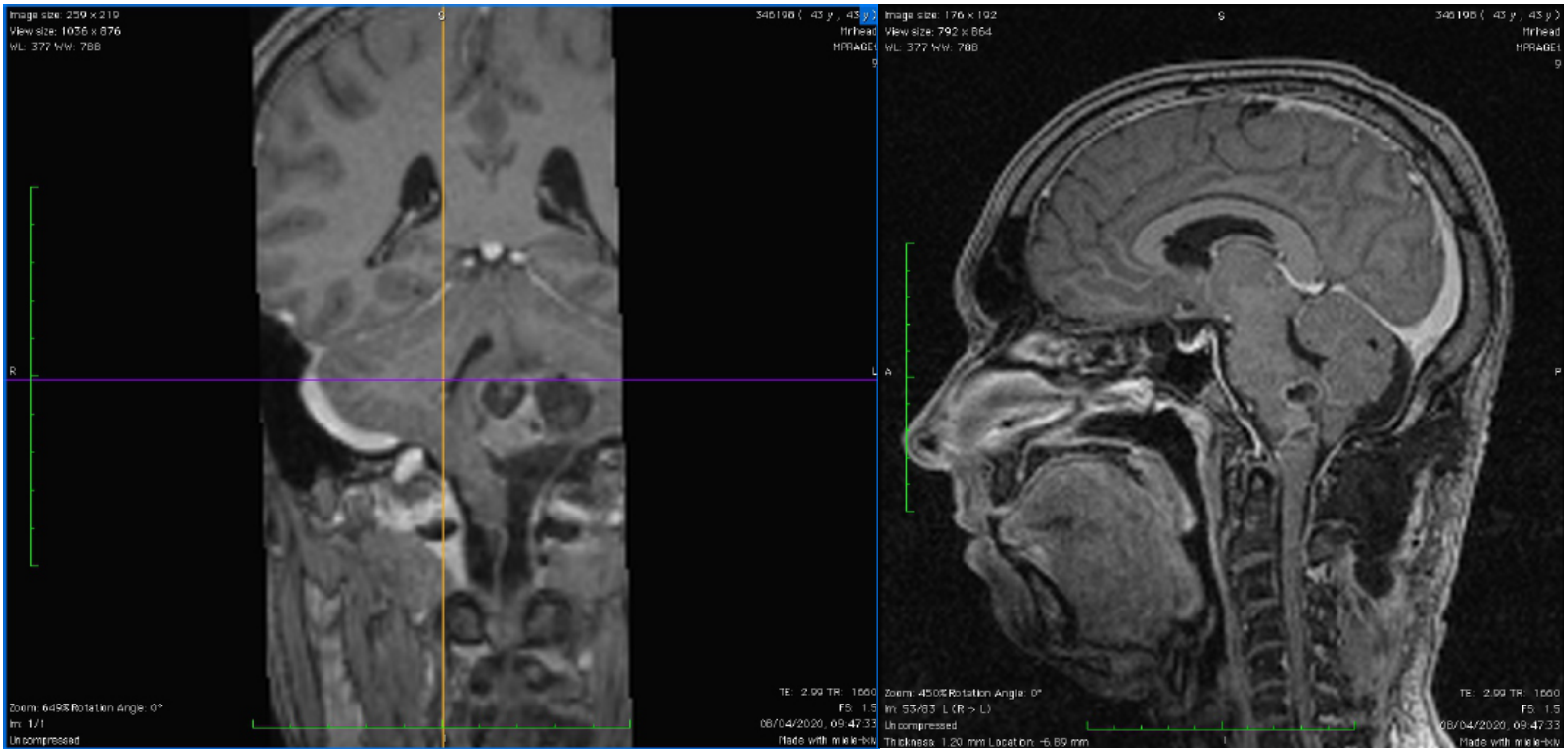

Figure 2. Postoperative coronal and sagittal T1 MRI depicts partial resection of the firmly adherent upper pole of the tumor to the brainstem and PICA.

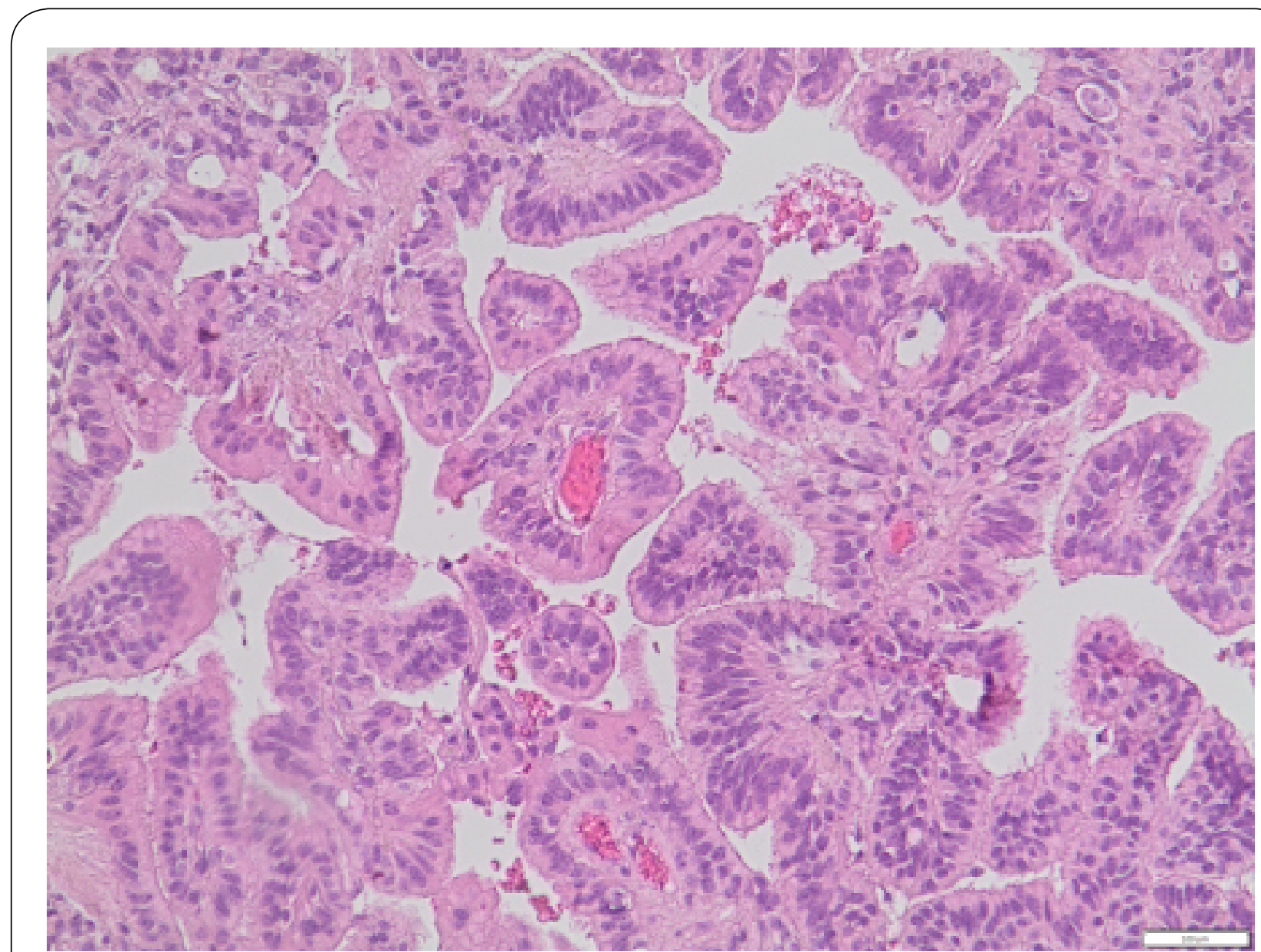

Figure 3. x20 Well-differentiated papillary pattern composed of a single layer of monomorphic cells. 


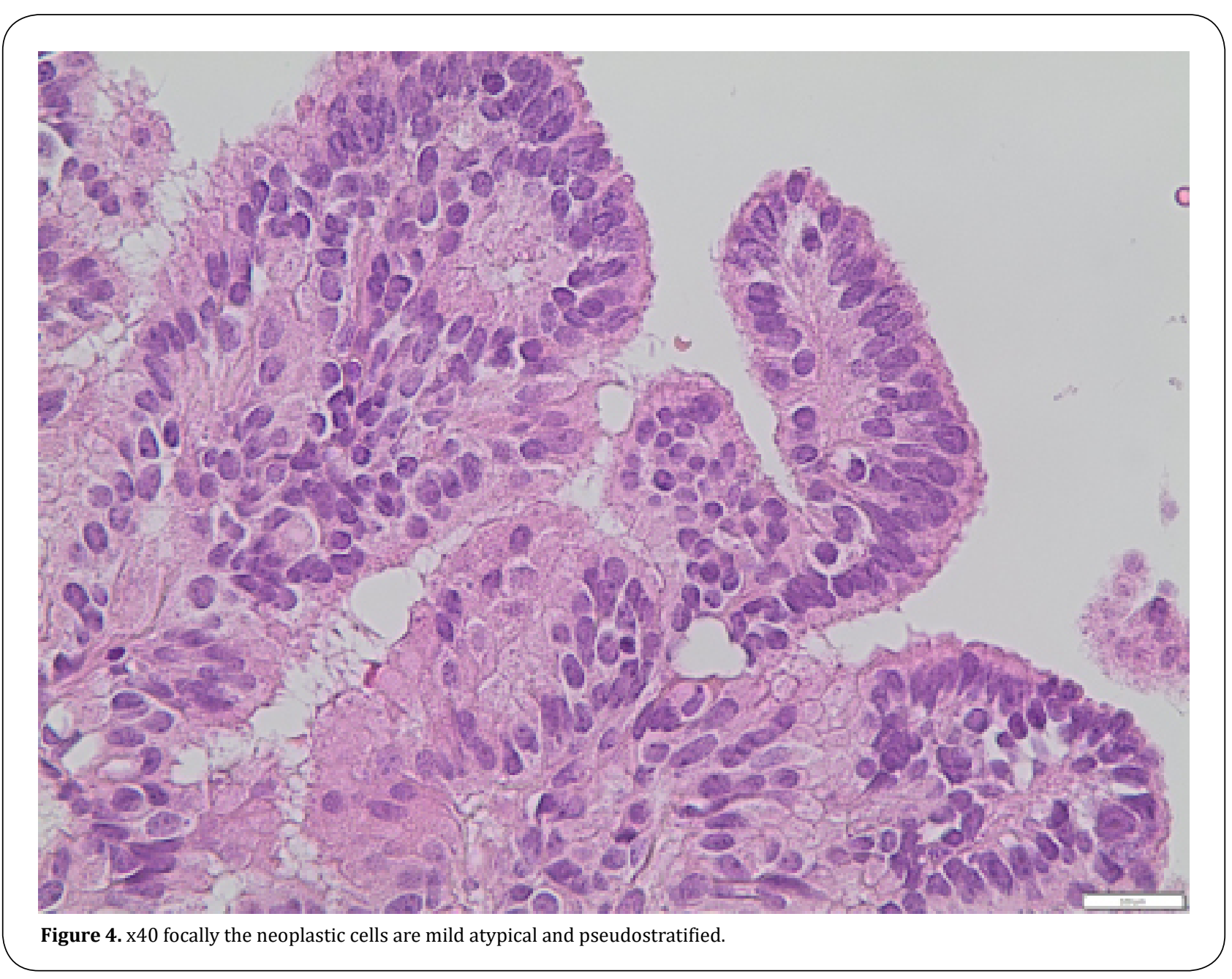

lower cranial nerves, vertebral artery and posterior inferior cerebellar artery (PICA). The vertebral artery and PICA were detached from the lower pole of the tumor using an arachnoid plane. Central debulking was performed with the Cavitron Ultrasound Aspirator. We recognized IX, X, XI, and XII nerves on the anterior and lateral parts of the tumor. The upper part of the tumor was located inside the cerebellomedullary cistern and was heavily calcified and firmly attached to the dorsal aspect of the medulla and the distal PICA. This part was left intact to prevent neurological injury (Figure 2). An artificial dura and tissue glue were used to seal any dural defects, and closure of the craniotomy was performed by replacing the bone flap with titanium mini plates.

\section{RESULTS}

The patient was extubated immediately after surgery without neurological deficit. The postoperative course was complicated by mild hoarseness of the voice, which gradually resolved. Fifteen days later, the patient was readmitted with fever and nuchal rigidity. Meningitis caused by an MRSA strain was diagnosed, and the patient treated for 15 days with intravenous vancomycin 1 gr twice per day. The meningitis resolved completely, and the patient was discharged.

The histological findings showed a well-differentiated papillary pattern composed of a single layer of monomorphic cells. The number of mitoses per 10 high power fields was two to five, so we diagnosed the tumor as grade II atypical choroid papilloma (Figures 3-5).

In our patient, choroid papilloma cells were stained $100 \%$ for s 100 which is a good prognostic feature (Figure 6) ${ }^{[10,11]}$.

\section{DISCUSSION}

The first-line treatment for CPP in all studies was surgical excision. Adjuvant treatment has been suggested 

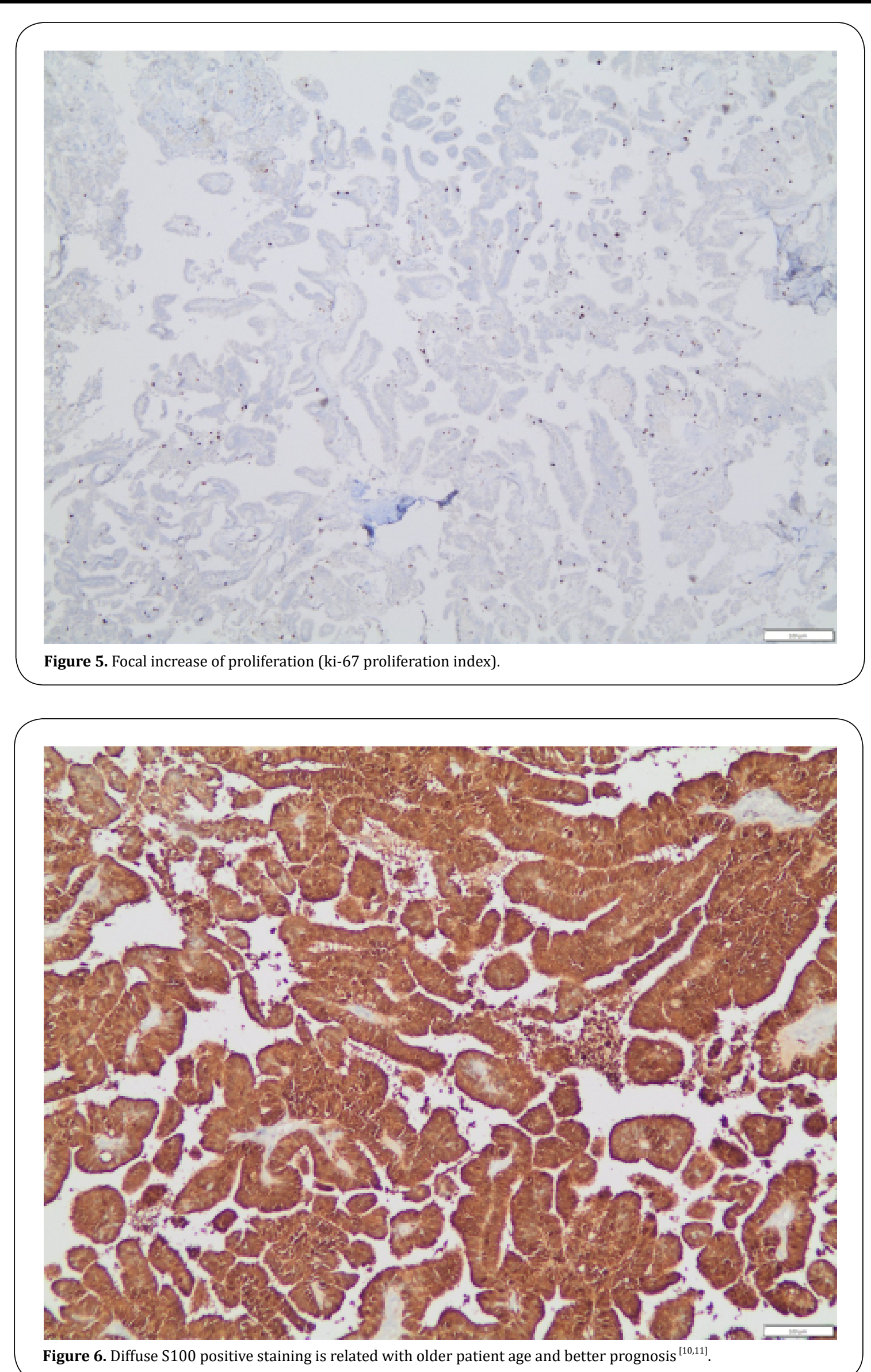
only for carcinoma and simple follow-up for benign CPPs ${ }^{[5]}$. Chemotherapy was suggested for choroid plexus carcinomas in infants and radiotherapy for choroid plexus carcinomas in adults ${ }^{[5]}$. However, the best strategy for atypical CPPs remains unclear.

The prognosis of CPP depends mainly on the histology. In a meta-analysis by Wolff et al., the 10 -year projected survival rate was reported as $77 \%$ for benign CPPs and $35 \%$ for choroid plexus carcinomas ${ }^{[5]}$. Relapse after primary treatment is a poor prognostic factor for carcinomas only in respect to benign papillomas.

\section{CONCLUSION}

Atypical choroid plexus papillomas are associated with an increased risk of recurrence or malignant transformation compared to "typical" papillomas. At present, complete surgical excision with close follow-up seems to be the most reliable treatment. Adjuvant chemotherapy or radiotherapy should be considered in cases of partial resection, recurrence, or dissemination.

\section{DECLARATIONS}

\section{Authors' contributions}

Made substantial contributions to interpret and analyse the images from the pathology examination: Tsantopoulos Margaritis, Spanou Kallirroi.

\section{Availability of Data and Materials}

Data and Material of this case report are stored in the medical archives of 251 General Air Force and Reserve Hospital, Athens, Greece.

\section{Conflicts of interest}

All authors declare that there is no conflict of interest.

\section{REFERENCES}

1. Jusue-Torres, I., Ortega-Zufiria, J. M., Tamarit-Degenhardt, M., \& Poveda-Nunez, P. D. (2012). Atypical choroid plexus papilloma in adults: case report and literature review. Neurocirugia (Asturias, Spain), 23(3), 116.

2. Joseph, J. J., \& Das, J. M. (2019). Choroid Plexus Papilloma. In StatPearls [Internet]. StatPearls Publishing.

3. Shin, J. H., Lee, H. K., Jeong, A. K., Park, S. H., Choi, C. G., \& Suh, D. C. (2001). Choroid plexus papilloma in the posterior cranial fossa: MR, CT, and angiographic findings. Clinical imaging, 25(3), 154-162.

4. Lechanoine, F., Zemmoura, I., \& Velut, S. (2017). Treating cerebrospinal fluid rhinorrhea without dura repair: A case report of posterior fossa choroid plexus papilloma and review of the literature. World Neurosurgery, 108, 990-e1.

5. Wolff, J. E. A., Sajedi, M., Brant, R., Coppes, M. J., \& Egeler, R. M. (2002). Choroid plexus tumours. British Journal of Cancer, 87(10), 1086-1091.

6. van Swieten, J. C., Thomeer, R. T., Vielvoye, G. J., \& Bots, G. T. (1987). Choroid plexus papilloma in the posterior fossa. Surgical neurology, 28(2), 129.

7. Matsushita, S., Shimono, T., Goto, T., Doishita, S., Kuwae, Y., \& Miki, Y. (2019). Posterior fossa choroid plexus papilloma with focal ependymal differentiation in an adult patient: A case report and literature review. Radiology Case Reports, 14(3), 304-308.

8. Yu, H., Yao, T. L., Spooner, J., Stumph, J. R., Hester, R., \& Konrad, P. E. (2006). Delayed occurrence of multiple spinal drop metastases from a posterior fossa Choroid plexus papilloma: case report. Journal of Neurosurgery: Spine, 4(6), 494-496.

9. Symss, N. P., Prasad, A. N., Vasudevan, M. C., \& Ramamurthi, R. (2009). Exophytic choroid plexus papilloma of the fourth ventricle presenting with cerebrospinal fluid rhinorrhea: a case report. Surgical neurology, 71(6), 705-708.

10. Paulus, W., \& Jänisch, W. (1990). Clinicopathologic correlations in epithelial choroid plexus neoplasms: a study of 52 cases. Acta neuropathologica, 80(6), 635-641.

11. Coffin, C. M., Wick, M. R., Braun, J. T., \& Dehner, L. P. (1986). Choroid plexus neoplasms: clinicopathologic and immunohistochemical studies. The American journal of surgical pathology, 10(6), 394-404. 